\title{
LEGITIMAÇÃO DO DIREITO PENAL POR PRINCÍPIOS RECONHECIDOS E INSERIDOS NAS CONSTITUIÇÕES DOS ESTADOS DEMOCRÁTICOS DE DIREITO
}

\author{
LEGITIMIZATION OF CRIMINAL LAW BY PRINCIPLES \\ RECOGNIZES AND INCORPORATED IN THE CONSTITUTION \\ OF DEMOCRATIC STATES OF LAW
}

\section{Maria Auxiliadora Minabim ${ }^{1}$}

UFBA

\begin{abstract}
Resumo
O artigo trata dos princípios garantidores do cidadão e de sua liberdade no âmbito do Direito Penal como recurso que pode permitir sua legitimação. Os fundamentos axiológicos do direito penal têm sede constitucional, sendo deduzidos do meta princípio da dignidade humana. Reconhece-se, entretanto que, apesar de estarem abrigados no topo do ordenamento, tais princípios podem ser frustrados por orientações eficientistas, inclusive na esfera processual. No cumprimento de sua missão, os princípios devem atuar conjuntamente, impedindo possíveis brechas que permitam o arbítrio. Propõe-se, também, que não sejam restringidos por pensamentos substancialistas que realçam a justiça material em detrimento da justiça formal.

Palavras-chaves

Princípios fundamentais do Direito Penal. Sede constitucional. Função garantidora das liberdades individuais
\end{abstract}

\section{Abstract}

The article deals with the citizen's freedom guarantor principles within the scope of Criminal Law, which can work as a resource for its legitimization. The axiological foundations of criminal law have a constitutional seat and are deduced from the fundamental principle of human dignity. It is recognized, however, that, although they are sheltered at the top of the legal order, such principles can be thwarted by efficiency guidelines, including the procedural sphere. They must act together, preventing possible loopholes through which the agency moves. They should not be restricted by substantialist thoughts that emphasize material justice over formal justice

Keywords

\footnotetext{
${ }^{1}$ Professora Titular da UFBA. Doutora em Direito pela Universidade Federal do Paraná e Doutora em Direito pela Universidade Federal do Rio de Janeiro.
} 
Revista da Faculdade Mineira de Direito $\mid$ v.20 N.40|71

Basic principles of criminal law - Constitutional seat - Ensurement of Civil liberties

\section{INTRODUÇÃO}

O Direito Penal sofre, no Estado liberal, dificuldades para sua legitimação enquanto recurso capaz de apresentar soluções justas e aceitáveis para importantes conflitos sociais. Reconhece-se que tal tarefa é difícil, à medida que este ramo do direito dispõe de meios que, postos à disposição do Estado, podem ser manipulados em seu favor, tornando difícil a justificação moral e política do sistema criminal.

Por isso mesmo, há quem afirme que Constituição e Direito Penal, durante longos anos, caminharam em sentidos opostos na medida em que a palavra "Constituição" evoca proteção da liberdade e Direito Penal, ao contrário, denota restrições aos direitos.

É de ressaltar, no entanto, que o Estado moderno assimilou, em seu percurso, novas conquistas do iluminismo, assentando seu ordenamento jurídico sobre os princípios da ilustração de forma a dispor de um modelo jurídico penal liberal e garantidor. Assim, é possível afirmar, embora não haja absoluta coincidência histórica, em razão de períodos de convivência de um direito, ainda cruel, com formas de governo já restringidas pelas liberdades dos súditos, que a constituição do direito criminal restringido em seu arbítrio, caminhou associada à contenção de exercício do poder estatal. O reconhecimento do Estado a partir da perspectiva dos indivíduos foi o que possibilitou, segundo Bobbio, "a doutrina do Estado liberal, que é in primis, a doutrina dos limites jurídicos do poder estatal'"[1]. Tais limites não são apenas formais, ou seja, não se trata de submissão do direito às leis, mas também destas a alguns direitos fundamentais reconhecidos constitucionalmente e, portanto, invioláveis, conforme o mesmo autor. [2] O pós-positivismo jurídico, a seu turno, ao restabelecer uma relação entre direito e ética, toma, como valor básico da ordem jurídica, o meta princípio da dignidade humana no qual se assentam outros valores igualmente 
Revista da Faculdade Mineira de Direito $\mid$ v.20 N.40 72

lastreados no respeito à pessoa. Assim, a modernidade ocidental, orientada por este super princípio, não só o insere no texto constitucional para que haja o reconhecimento de sua normatividade, mas dele faz defluir outros que lhe dão substancialidade.

O reconhecimento jurídico da dignidade da pessoa humana como valor positivado na Constituição tem desdobramentos expressivos nos subsistemas normativos internos. A preservação do valor da pessoa e o asseguramento de seus direitos essenciais passam a constituir os ideais perseguidos pelos sistemas jurídicos liberais, aos quais se alinha, necessariamente, o Direito Penal na tentativa de sua legitimação. A subsunção a esta meta é o caminho mais promissor para justificar seu exercício quando se imiscui, coercitivamente, na esfera de liberdade de outrem.

A Constituição de 1988 elenca os dispositivos essenciais e determinantes de um direito penal cuja validade decorre do respeito à liberdade do cidadão sem perder de perspectiva os imperativos de justiça material. Assim, o da legalidade, o da proibição de retroatividade in pejus, o da coisa julgada dos quais por sua vez, procedem outros, conforme interpretação do STF, a exemplo, da proporcionalidade.

O trabalho, a partir de pesquisa bibliográfica de autores nacionais e estrangeiros, da área de direito penal e de direitos humanos, tem como objetivo destacar que, grande parte dos Estados do ocidente, apesar de suas divergências, tem como ponto comum um programa de obrigações constitucionais, no qual a afirmação da dignidade humana ganha centralidade. Propõe-se que seja com base nesse valor que as normas penais devam ser compreendidas e interpretadas, conferindo legitimidade a este ramo do direito.

\section{OS PRINCÍPIOS COMO UM BLOCO BLINDADO DE PROTEÇÃO}

É essencial que se destaque que os princípios, embora guardem características que os distinguem, sendo possível, facilmente individualizalos, apenas cumprem sua função constitucional quando agem 
Revista da Faculdade Mineira de Direito $\mid$ V.20 N.40 $\mid 73$

conjuntamente. Desse modo, não há legalidade, por exemplo, sem: taxatividade, lei escrita, irretroatividade. Não poderá haver respeito à dignidade, permitindo-se que um indivíduo possa ser julgado duas vezes pelo mesmo fato, o que amplia as possibilidades de violação de direitos do réu através do arbítrio de Estado inconformado com a decisão judicial passada em julgado. Assim, outros dispositivos constitucionais vêm complementar a missão da qual se incumbem os princípios.

Muitas vezes, apesar da barreia oposta ao indevido cerceamento das liberdades, é possível que a prática, como diz Ferrajoli, "seja esmaecida por orientações eficientes e pragmáticas"[3]. Em verdade, não obstante a procura de fundamentos axiológicos que garantam o cidadão diante do arbítrio estatal e sua incorporação no plano da maioria das constituições, não se pode negar a ocorrência de violações às liberdades inerentes à pessoa humana.

O efeito assustador da mitigação dos ideais liberais tem impulsionado, por outro lado, a procura de novas alternativas capazes de concretizar aquelas aspirações da Modernidade, ainda que essas não tenham se cumprido com o projeto por ela sugerido. Não é demais lembrar que a preocupação em reforçar os limites do poder político ganhou expressiva força após a Segunda Grande Guerra. Assim, são deduzidas, a partir dos fundamentos axiológicos, outras orientações compatíveis com as bases do Estado de Direito de forma a diminuir a distância entre o discurso oficial e as práticas, algumas vezes, contraditórias.

O modelo garantista de Ferrajoli, por exemplo, introduzido no país no período de redemocratização, assim como o foi em outros países da América Latina, a exemplo do México, Colômbia e na Argentina, constitui uma inspiração na reconstrução democrática do direito brasileiro. É possível, como diz Bobbio, que não seja um exemplo acabado, mas "um modelo ideal de cuja realidade se pode mais ou menos aproximar"'4] o qual, como a utopia habermasiana, acrescente-se, talvez, não possa jamais ser alcançado, mas deve sempre ser buscado. Ademais, sua repercussão no mundo jurídico revela que o ideal de liberdade permanece entre nós, não tendo se perdido, mesmo após períodos de impiedosos atentados contra os direitos da humanidade. 
Revista da Faculdade Mineira de Direito $\mid$ V.20 N.40 74

Com efeito, Ferrajoli postula a elaboração de uma teoria geral do garantismo cuja finalidade é a proteção das liberdades do cidadão, em conformidade com os princípios da tradição jurídica liberal, os quais foram incorporados nos Códigos e nas Constituições modernas. Com vistas a ampliar a esfera de garantias individuais, o autor não se satisfaz como a ideia da "mera" legalidade (enunciado formal das proibições na lei), para exigir a estrita legalidade, ou seja, que tais enunciados sejam dotados de referências fáticas precisas, referíveis. Com este esquema passível de comprovação, evita-se a punição de pessoas em razão de suas características pessoais e os magistrados ficam obrigados a relacionar a conduta punida a fatos empiricamente verificáveis. Ademais, a partir dos axiomas enunciados, contendo garantias que devem anteceder o juízo de responsabilidade, se oferece uma espécie de pauta para aferição da liberalidade ou não do Direito Penal em um determinado Estado. Como consequência, e nas palavras do autor, constituem "um esquema epistemológico de identificação do desvio penal" capaz, portanto capaz de orientar o processo de restauração da democracia [5].

Ademais, tem-se repudiado a chamada legalidade substancial que avoca o imperativo da justiça concreta, conforme Luiz Luisi [6] que tem afrontado a legalidade e a irretroatividade ensejando o arbítrio. Daí a acolhida ao formalismo apregoado por Ferrajoli [7] em contraposição ao substancialismo que considera o delito como "desvio criminal enquanto em si mesmo imoral ou antissocial e, para além dele a pessoa do delinquente Tal percepção ontológica do crime pretende superar a validade formal de um princípio garantidor o que a torna incompatível com um ordenamento que tenha agasalhado os direitos fundamentais de liberdade. Aliás, deve-se salientar as divergências entre os sistemas nacionais e o entendimento de Cortes Internacionais, não só a respeito da legalidade como da prescrição e irretroatividade com o objetivo de atender à legalidade substancial, que põe em cheque o rol de garantias duramente conquistadas. 
Revista da Faculdade Mineira de Direito |V.20 N.40|75

\section{PRINCÍPIOS CONSTITUCIONAIS APLICÁVEIS AO DIREITO PENAL}

Alguns princípios penais constitucionais têm fundamentos externos e, como se reafirma ao longo dessa exposição, se identificam com aqueles que sustentam o Estado liberal. Outros, embora derivem da Constituição e se voltem também para a salvaguarda do direitos, liberdades e garantias, têm conteúdo especialmente penal e integram o ordenamento positivo. Dentre estes, releva o da legalidade que constitui a própria missão e fim do Direito Penal, no dizer de Hassemer [8] e não apenas uma de suas características.

A legalidade revigora o compromisso inarredável do Direito Penal com a salvaguarda dos direitos, liberdades e garantias e, também, tem fundamentos externos, dos quais Jorge Figueiredo Dias [9] destaca o princípio liberal, o princípio democrático e o princípio da separação de poderes. Disto resulta que toda atividade do Estado que se imiscua na esfera de liberdade dos cidadãos deve resultar de lei formal, emanada do Congresso, Poder que representa o povo. Essa compreensão reafirma o nexo entre liberdade e legalidade, dando origem a outros princípios essenciais para concretização do ideal postulado

A legalidade foi expressamente reconhecida na declaração de Direitos do Homem e do Cidadão de 1789 e acolhida, posteriormente, pelo artigo $7^{\circ} \mathrm{da}$ Constituição francesa de 1895 com a seguinte formulação: tudo que não é proibido pela lei não pode ser impedido e ninguém pode ser obrigado a fazer o que esta não ordena fazer. Feuerbach foi, porém, o autor que introduziu o princípio na dogmática penal, com consagrado princípio expresso na fórmula latina nullun crimen nulla poena sine lege.

A Constituição brasileira de 1988 no art. 5º inciso II, estabelece que "ninguém será obrigado a fazer ou deixar de fazer alguma coisa senão em virtude de lei", enunciado de caráter geral, mais adiante, no inciso XXXIX do artigo $5^{\circ}$, especializa a prescrição com relação ao Direito Penal dispondo "não haverá crime sem lei anterior que o defina, nem pena sem prévia cominação legal ". 


\section{Revista da Faculdade Mineira de Direito | V.20 N.40|76}

Como consequência do princípio, fica proscrita a analogia, ou seja, a aplicação da lei a um fato concreto nela não tratado, recorrendo-se à semelhança entre um e outro caso sempre que ela prejudique o agente. A vedação à analogia se estende, portanto, ao juiz que está impedido de condenar ou agravar as consequências jurídicas através de seu uso. Considerando que, conforme Zaffaroni [10], os princípios penais não são dogmáticos, mas obtidos previamente ao próprio método, a vulneração de um deles atinge os fundamentos do próprio Direito Penal e os resultados que pretende alcançar, como se afirma nesse trabalho.

Os tribunais brasileiros a respeito da matéria têm decidido que:

Em Direito Penal, o princípio da reserva legal exige que os textos sejam interpretados sem ampliações ou equiparações por analogia, salvo quando in bonam parte. Ainda vige o aforismo poenalia sunt restringenda, ou seja, interpretam-se estritamente as disposições cominadoras de pena (RT $594 / 365)$.

A reserva legal desdobra-se, também na exigência de delitos escritos de forma clara, de modo a evitar-se não só a vedação de violações contra a proibição de uso da analogia, mas, também para realizar a taxatividade, isto é, a legalidade estrita. De acordo com Ferrajoli [11], a norma é dirigida ao legislador a quem cabe evitar o uso excessivo de elementos normativos e de conceitos abertos, indeterminados, os quais facilitam interpretações extensivas por parte dos magistrados. Com vistas a atender a esse fim, devese proscrever as convenções penais referidas "não a fatos, mas diretamente a pessoas e, portanto, com caráter constitutivo e não regulamentar daquilo que é punível". Os doutrinadores brasileiros incorporam esse princípio em suas obras e ressaltam sua importância para a fixação de marcos legais nítidos no ordenamento jurídico penal nacional.

A posição dos tribunais ratifica essa compreensão, como se pode constatar: 


\section{Revista da Faculdade Mineira de Direito $\mid$ V.20 N.40|77}

Ementa: Habeas Corpus. Condução de veículo automotor sob efeito de álcool. Art.306 da Lei no 9.503/97. Advento da Lei $\mathrm{n}^{\circ} 11.705 / 2008$. Inclusão de parâmetro objetivo à elementar do tipo penal. Necessidade de realização de teste de alcoolemia previsto no Decreto $\mathrm{n}^{\circ} 6.488 / 2008$ para a adequação típica. Ocorrência. Ordem denegada. A taxatividade objetiva determinada pela nova redação do art. 306 do Código de Trânsito Brasileiro, que fixou como indesejável a dosagem igual ou superior a 6 decigramas de álcool por litro de sangue, deve ser atendida mediante a realização de um dos testes de alcoolemia previstos no Decreto $n^{\circ} 6.488 / 08$, que são: exame de sangue ou teste em aparelho de ar alveolar pulmonar etilômetro). Constatada a realização do chamado "teste do bafômetro", não há que se falar em falta de justa causa para a ação penal. Ordem denegada.

A taxatividade, quando se refere à clareza da norma, dirige-se também ao seu destinatário para que este possa compreender de forma inequívoca o conteúdo do seu comando, não só para que a função intimidativa da pena possa ser cumprida, mas sobretudo, para proteger o cidadão do arbítrio judiciário. De fato, tipos cujo preenchimento é submetido apenas à vontade do juiz ferem a certeza e segurança jurídicas necessárias a um regime de proteção aos direitos de liberdade.

Deve-se afirmar também que, como decorrência da legalidade, a única fonte imediata do Direito Penal é a lei, lei escrita, de forma que o costume, tem função acessória, quando se trata das normas incriminadoras. Tal acessoriedade consiste na possibilidade de interpretar o conteúdo de uma norma para que seu preceito se ajuste ao sentido social dominante. Assim ocorre diante de textos equívocos nos quais, para que o fim pretendido pela norma seja alcançado, é necessário o recurso aos costumes, dando à lei um sentido compatível com as relações sociais vigentes.

Como bem explicita Aníbal Bruno ${ }^{[12]}$, na seara das normas estritamente incriminadoras, o costume só é admissível em hipóteses assim limitadas, impedindo que tenha idoneidade para criar ou integrar tipos penais em suas lacunas, a exemplo do que já ocorreu em Roma onde os magistrados decidiam ad exemplum legis. 
Revista da Faculdade Mineira de Direito $\mid$ V.20 N.40 78

Essas exigências buscam evitar que as leis, em sua aplicação, abram espaço para a arbitrariedade, favorecendo, ao inverso, que o Direito Penal também possa contribuir para a construção de uma sociedade justa.

Questão controversa e que atenta contra a legalidade formal diz respeito à chamada legalidade substancial que avoca o imperativo da justiça concreta, conforme Luiz Luisi [13] que pode ensejar o arbítrio. Ferrajoli [14] apregoa o formalismo em contraposição ao substancialismo que considera o delito como "desvio criminal enquanto em si mesmo imoral ou antissocial e, para além dele a pessoa do delinquente". Tal percepção ontológica do crime pretende superar a validade formal de um princípio garantidor o que a torna incompatível com um ordenamento que tenha agasalhado os direitos fundamentais de liberdade. Aliás, deve-se salientar as divergências entre os sistemas nacionais e o entendimento de Cortes Internacionais, não só a respeito da legalidade como da prescrição e da irretroatividade com o objetivo de atender à legalidade substancial, que põe em cheque o rol de garantias duramente conquistadas.

É importante que se destaque aqui que ao tratar da validade formal incontestável da lei, refere-se a determinado ordenamento jurídico, qual seja, aquele afinado com os princípios garantidores das liberdades fundamentais. Para Santiago Mir Puig [15], há nessa visão do imperativo legal considerações anteriores ao direito penal, a exemplo do fato de ser o mesmo a expressão da vontade popular emitida pelo Poder Legislativo.

\section{1 A IRRETROATIVIDADE IN PEJUS}

Com a exigência de lei prévia - ou seja legalidade - se expressa também a proibição de retroatividade das leis que criem novos tipos ou agravem de qualquer forma a situação do acusado.

A não retroatividade da lei é "princípio de garantia e estabilidade da ordem jurídica, sem o qual faltaria a condição preliminar de ordem e firmeza nas relações sociais e de segurança dos direitos do indivíduo". Tal entendimento é atualizado pelo parecer de Luiz Regis Prado [16] que adverte a respeito da impossibilidade de alguém ser sancionado por fato que era irrelevante para o 
Revista da Faculdade Mineira de Direito $\mid$ V.20 N.40 79

Direito Penal, citando em seu favor Maurach, no mesmo sentido. É auto evidente, aliás, o poder de contenção do princípio, que é afastado, como lembra Luiz Luigi [17], quando se busca suprimir as garantias individuais em Estados totalitários, como ocorreu na antiga União Soviética e na China. Da mesma forma ocorreu em governos nos quais vigia o absolutismo do poder público na defesa dos interesses do príncipe.

Os mais festejados autores contemporâneos, a exemplo de Roxin][18], explicam que do nullun crimen são deduzidas quatro consequências sob forma de vedações, ora ao juiz (analogia e recurso ao direito consuetudinário para fundamentar ou agravar a pena) e ora ao legislador (retroatividade e criação de leis penais indeterminadas ou imprecisas). Jorge Figueiredo Dias [19] expressa o mesmo pensamento ao afirmar que a matéria da legalidade, se estende a todas suas consequências, incluindo a impossibilidade de retroatividade, reforçando a importância da compreensão dos princípios como um bloco.

Por óbvio, a retroatividade benéfica em supostos de conflito temporal de normas não está incluída no âmbito da proibição, porque a hipótese realiza uma missão do Direito Penal liberal. Nesse sentido, posicionam-se tanto a Constituição Federal, no inciso XL, artigo $5^{\circ}$, quanto o Código Penal no parágrafo único do artigo $2^{\circ}$.

A proibição de retroatividade in pejus é um dos pilares do conceito de legalidade e umas das manifestações mais rigorosas de segurança jurídica, expressão cujo sentido não pode ser dissociado da ideia de liberdade. Retroagir apenas em busca de justiça afeta, indelevelmente, a liberdade individual como valor essencial do Estado de direito. Bacigalupo [20], a propósito, observa que, embora a justiça seja um dos valores predominantes do ordenamento espanhol, ela o é conjuntamente com a liberdade. Desta forma, prossegue, o valor justiça não pode reduzir o valor liberdade de forma tão considerável que este resulte praticamente anulado

Matéria ainda polêmica sobre a retroatividade, diz respeito à jurisprudência a qual não pode ser propriamente considerada como violação da legalidade, embora não deixe de afetar o conhecimento do agente quanto ao pleno conhecimento do ilícito praticado. Ademais, conforme Wessel [21], há os que dizem que interpretação da lei está intimamente a ela associada, de forma que, em nome do princípio da legalidade, a compreensão judicial válida é 
Revista da Faculdade Mineira de Direito $\mid$ V.20 N.40 80

aquela da época do fato. Em seu entendimento pessoal, no entanto, o autor ensina que não pode jamais haver retroatividade contra o agente. Assim, a jurisprudência está sujeita à proibição de retroatividade, a menos que a nova compreensão traga novos dados, mas mantenha-se fiel ao texto da lei.

O Brasil, de forma divergente de outros Estados tem um pensamento mais liberal e entende que a proibição de retroatividade se estende às medidas de segurança, na medida em que estas guardam, assim como a pena, um caráter aflitivo. Na Alemanha, a posição majoritária é no sentido de que nessa matéria deve vigorar a lei da época da sentença[22]. Já em Portugal, Maria João Antunes [23] afirma, ao contrário do pensamento majoritário até então dominante que, se o fundamento da medida de segurança é a periculosidade, deverá valer a lei do tempo em que tal juízo for formulado.

\subsubsection{Irretroatividade de normas processuais penais}

No direito processual, como regra geral, não rege o princípio de proibição de retroatividade, aplicando-se ao ato em curso a norma então vigente. Embora a regra do tempus regit actum garanta o andamento do processo e evite a duplicação desnecessária de atos pelo Ministério Público, muitas vezes, a regra pode opor-se a garantias constitucionalmente estabelecidas em favor da liberdade do cidadão.

Com vistas a evitar uma compreensão estreita desse princípio processual, vêm se propondo critérios que possibilitam distinguir quando é ou não possível pensar em retroatividade da lei processual à luz de outros princípios estruturantes do Estado liberal.

Roxin [24] entende, de forma acertada que, sempre que se tratarem de atos puramente impulsionadores do processo, não há que se invocar a legalidade para impedir a retroatividade uma vez que tal princípio não se estende à proteção de lacunas processuais. Tratando-se de normas meramente procedimentais, portanto, que não afetam as garantias individuais, a exemplo do que ocorre com aquelas que alteram tão-só o processamento dos recursos, a forma de expedição ou cumprimento de cartas rogatórias, por exemplo, o artigo art. $2^{\circ}$ do Código de Processo Penal terá aplicação imediata como regra geral, alcançando o processo no Estado em que se encontra. 


\section{Revista da Faculdade Mineira de Direito $\mid$ V.20 N.40| 81}

Há outras normas, no entanto cuja aplicação imediata afeta direitos e garantias, como lembra o mesmo autor [25], recorrendo ao exemplo de lei posterior que venha a derrogar os pressupostos processuais de outra, afastando, por exemplo, a necessidade de queixa em um crime de ação privada. $\mathrm{O}$ direito de punir criado pela lei posterior não pode ser aplicado imediatamente, porque estaria criando uma possibilidade de intervenção penal. Da mesma forma deve ser a compreensão quando se trata de pressuposto de impedimentos que afetam o processo como um todo, a exemplo da prescrição, uma vez que a reabertura de prazos já transcorridos afeta a segurança jurídica.

Félix María Pedreira González [26] propõe uma regra geral para a consideração ou não da proibição de retroatividade que consiste na apreciação da norma à luz dos princípios constitucionais e dos fundamentos jurídicos e axiológicos da irretroatividade. Por isso mesmo, inclui entre seus exemplos de proibição, aquele que altera condições para a prisão provisória e afeta o status de liberdade do acusado.

Assim, a corrente que entendia que a restrição da proibição de retroatividade limitava-se ao direito material vem sendo superada por esta outra na qual o fundamento primeiro da irretroatividade não está vinculado à natureza da norma, mas à sua substancia, i. e., se atinge ou não direitos individuais e amplia o arbítrio do Estado.

Paulo Queiroz [27] soma um argumento de política criminal que reforça essa posição ao lembrar que tem sido crescente o recurso à norma processual "como instrumento de uma política criminal eficientista, que, a pretexto de maximizar o controle da criminalidade, vem de minimizar garantias".

O entendimento prevalente, portanto, é que os atos praticados com fundamento na lei nova, estando o processo em curso, aplicam-se ao momento processual, desde que o status de liberdade do agente não seja afetado. Desta forma têm decidido o Tribunal Constitucional espanhol e o alemão, orientando no sentido de que se aprecie, preliminarmente, o Estado de liberdade do cidadão, para considerar, qual é a lei processual mais favorável ao agente. 
Revista da Faculdade Mineira de Direito $\mid$ V.20 N.40 $\mid 82$

A doutrina e a jurisprudência estão acordes com essa orientação, havendo manifestações tanto do STF quanto do STJ nesse sentido ${ }^{2}$.

\section{COISA JULGADA MATERIAL}

Como se tem destacado ao longo do texto, o Direito Penal constitui a mais gravosa forma de intervenção estatal nos direitos fundamentais da pessoa humana, ser dotado de dignidade, valor já elevado à condição de norma jurídica. Em assim sendo, o ser humano deixa de ser objeto de ingerência do Estado e passa a ser identificado como sujeito possuidor de direitos oponíveis a este, com o status e dimensão indispensáveis ao respeito de tal dignidade 46. E não poderia ser diferente, a imposição de pena e o simples processo penal, ao qual o suposto autor do delito é submetido pelo Estado, constituem, por si só, uma invasão no âmbito pessoal dos indivíduos. Por isso mesmo o poder punitivo precisa de limites opostos por garantias invioláveis.

Considera-se a coisa julgada material como a coisa julgada por excelência, de forma que o uso da expressão coisa julgada sem adjetivação, significa coisa julgada material.

A Constituição brasileira, em seu art. $5^{\circ}$, inciso XXXVI, agasalha a coisa julgada nacional, garantia essa já posta a salvo pelo art. $6^{\circ}$ da Lei de Introdução ao Direito Brasileiro, lei autônoma e independente que traduz

${ }^{2}$ RECURSO. Extraordinário. Pedido. Inconstitucionalidade do art. 411 do Código de Processo Penal. Dispositivo revogado pela Lei $n^{\circ} 11.689 / 2008$. Perda superveniente do interesse recursal. Recurso prejudicado. O pedido da recorrente está prejudicado ante a revogação do art. 411, do Código de Processo Penal, pela Lei $n^{\circ} 11.689 / 2008$, que introduziu, no art. 415, novas regras para a absolvição sumária nos processos da competência do Tribunal do Júri. 2. AÇÃO PENAL. Tribunal do Júri. Absolvição sumária imprópria. Revogação do art. 411, do Código de Processo Penal, pela Lei nº 11.689/2008. Retroatividade da lei mais benéfica. Concessão de habeas corpus de ofício. As novas regras, mais benignas, aplicam-se retroativamente. Ordem concedida para que o juízo de $1^{\circ}$ grau examine, à luz da nova redação, se estão presentes os requisitos para a absolvição sumária, oportunizada prévia manifestação da defesa. RE 602561/SP - SÃO PAULO. RECURSO EX TRAORDINÁRIO. Relator (a): Min. CEZAR PELUSO. Julgamento: 27/10/2009 Órgão Julgador: Segunda Turma. 
Revista da Faculdade Mineira de Direito | V.20 N.40| 83

um conjunto de normas e regras aplicáveis a todos os ramos do Direito. Constitui, desta forma, um alicerce no direito brasileiro, impedindo a mutabilidade de sentença com trânsito em julgado, quer por haver ocorrido a exaustão das vias recursais, quer pela não interposição do recurso cabível no prazo estipulado pela lei.

A coisa julgada, na esfera processual, é prevista tanto pela norma processual civil quanto pela norma processual penal, constituído a primeira constitui regramento de aplicação subsidiária à esfera processual da segunda.

Trata-se de princípio decorrente apenas da atividade jurisdicional, com amparo constitucional, conforme ressaltado, que torna determinadas sentenças imunes a controvérsias futuras, vedando que a mesma seja modificada ou que seja rediscutida e processo subsequente.

A coisa julgada já havia sido objeto de consideração de Chiovenda que a tratava como o bem que se torna incontestável à parte que teve seu pleito não acolhido. De acordo com o autor, "o bem julgado torna-se incontestável (finem controversiarum accipit) " [28], por isso mesmo aquele a quem foi reconhecido um direito, "não só tem o direito de consegui-lo praticamente, em face de outra, mas não pode mais sofrer, por parte desta, ulteriores contestações a esse direito e gozo"49. Assevera, contudo que a coisa julgada não consiste na afirmação da verdade dos fatos, como desejava o Código Civil francês do séc. XIX, mas sim da existência da vontade da lei no caso concreto. A razão de ser do instituto reside na necessidade de se preservar a segurança e pacificidade da vida social, permitindo aos seus componentes tranquilidade no gozo dos bens da vida[29].

A coisa julgada, como as demais previsões normativas, possui determinados limites e, conforme já asseverava o antigo Código de Processo Civil, não recai sobre todo conteúdo da sentença, não havendo vinculação das partes aos motivos utilizados para fundamentar o mandamento, nem à suposta veracidade ou não dos fatos suscitados pelas partes no curso do processo, da mesma maneira que não transitam em 


\section{Revista da Faculdade Mineira de Direito $\mid$ V.20 N.40| 84}

julgado nem vinculam as partes à decisão incidente sobre questões prejudiciais enfrentadas.

O instituto permite que um processo passe a ostentar uma afirmação categórica "para o cumprimento: irrevogabilidade (dimensão interna ou efeito intraprocessual), de um lado, e, de outro, eficácia frente a eventuais discussões posteriores em torno do que foi resolvido no processo" [30]. A principal característica da coisa julgada no processo criminal, todavia é que seu objeto não é o comando produzido na norma pura e simplesmente, mas sim o fato ou a pluralidade de fatos jurídicos submetidos à julgamento, sobre os quais tenha se operado a preclusão máxima.

Conforme os ensinamentos de José Frederico Marques [31], a coisa julgada em processo criminal opera em relação ao fato principal, objeto da sentença, independentemente de sua classificação penal. Desse modo, o fato principal não pode ser acrescido de dados acessórios, com vistas a ser submetido a novo processo, sob pena de se configurar o inadmissível bis in idem. Isso se deve ao fato de que, ao contrário do que ocorre em sede de processo civil, o julgamento do fato penal não está adstrito à classificação jurídica proposta nos pedidos em sede de petição inicial. Aponta, o autor, que o art. 383 do Código de Processo Penal consagra o princípio da narra mibi factum, dabo tibi jus.

Em suas palavras [32]:

A ação penal e o processo devem versar sobre o fato delituoso em sua integralidade. Para o juiz decidir da acusação, as omissões de circunstâncias que alteram a fisionomia legal do fato imputado são relevantes, pois que impedem a qualificação jurídica da imputação sob outra forma [...].Todavia, em se tratando da identificação da lide penal, o mesmo se não verifica, visto que as circunstâncias e pormenores, os elementos acessórios e complementares em nada influem no fato principal que a imputação descreve, porque nesta é que se contém causa petendi que identifica o pedido acusatório e o litígio penal.

O pensamento supra referido possui total coerência com o sistema penal vigente que, até os dias atuais, mantém o instituto conhecido como a 
Revista da Faculdade Mineira de Direito $\mid$ V.20 N.40 85

emendatio libelli contido art. 383 do Código de Processo Penal. Essa construção permite que o juiz promova nova capitulação jurídica do fato sub judice, ainda que desta prática se imponha pena mais gravosa ao réu, desde que o magistrado mantenha a correlação entre os fatos narrados na inicial e a sentença. Não é outra a compreensão que se pode extrair de tal enunciado, senão a de que, independentemente dos pedidos formulados pelo Parquet ou querelante, o acusado se defende dos fatos e a eles o processo criminal e a coisa julgada se vinculam.

O fundamento jurídico da coisa julgada reside no interesse público de paz social, uma vez que é socialmente conveniente que os litígios cheguem a uma conclusão final. Assim mesmo entende Fernando Tourinho Filho [33], para quem seria danoso à sociedade que as discussões jurídicas tivessem um processamento e recursos de impugnação intermináveis.

Câmara [34] lembra, contudo, que não se deve confundir o já exposto sobre a imutabilidade da sentença que faz coisa julgada sobre um fato com a sentença cujo conteúdo contraria fundamento constitucional, e que não deve subsistir, uma vez que a inconstitucionalidade consiste em vício insanável.

No campo do Direito Processual Penal, a possibilidade de relativização da coisa julgada frente a decisões absolutórias não é sequer suscitada, posto que o bem jurídico sacrificado em uma sanção penal é a liberdade, direito fundamental sem o qual o indivíduo tem sua dignidade drasticamente afetada. Isso leva o processo penal a considerar de maneira muito mais rígida a possibilidade de revisão da matéria julgada quando comparado às possibilidades elencadas pela norma processual civil.

As hipóteses previstas no direito processual brasileiro de controle do decisum não incluem a suposta injustiça do conteúdo da sentença, caso em que "ocorreria violação de princípios e direitos fundamentais ao homem" [...] conferindo-se ao magistrado uma possibilidade de revisão da coisa julgada que neste não tem e que permitiria diversas interpretações, "em prejuízo da segurança jurídica. [...] A coisa julgada material é atributo do Estado Democrático de Direito[...]" [35].

O instituto da coisa julgada não está comprometido, portanto, com a verdade, nem com a justiça da decisão, mas sim com a necessidade política 


\section{Revista da Faculdade Mineira de Direito $\mid$ V.20 N.40| 86}

de preservação da estabilidade e seguranças sociais proporcionada pela imutabilidade da decisão, pensamento com o qual se afina Luiz Fux [36]. A ideia não se abate, dessa forma, diante do conceito de "injustiça", que é amplo e atingiria fatalmente o instituto da coisa julgada. Valendo-se de conceitos fluídos de justiça ou injustiça, qualquer matéria poderia ser submetida a novo julgamento, bastando, para tanto, que a parte sensibilizasse o magistrado com sua argumentação acerca da suposta injustiça da matéria, fazendo-o admitir a reanálise dos fatos.

\section{CONCLUSÃO}

A sujeição do Direito Penal aos princípios constitucionais é um imperativo nos Estados nos quais a carta política estabelece um Estado Democrático de Direito. Entende-se que, algumas vezes, nem mesmo este modelo pode evitar abusos contra o conjunto de direitos reconhecidos ao indivíduo perante o Estado em razão de artifícios engendrados para fazer prevalecer o jus puniendi sobre as liberdades asseguradas. Por isto mesmo, não é possível transigir com qualquer interpretação que possa restringir princípios que, desde o Iluminismo, compreendem o cidadão como a razão de toda ação estatal.

De fato, a legitimação do Direito Penal, é sempre afetada pelo uso da força que, aliás, lhe é inerente, razão pela qual se impõe seja contida pelos fundamentos axiológicos que devem orientar toda a prática criminal. Os princípios penais constitucionais expressos na Constituição contêm uma história que persegue o ideal de liberdade e respeito à dignidade humana. Apesar de sua força e de guardarem identidade própria, é imprescindível que tais normas funcionem como um bloco, na medida em que sua validez depende de uma articulação inflexível. A legalidade, conquista da Ilustração, pode por exemplo, ser vulnerada, se não lhe coadjuvam, taxatividade e irretroatividade ou se o Processo Penal não for cercado de providências garantidoras.

Ademais, apesar dos conflitos suscitados entre justiça material e justiça formal, deve-se honrar a justiça formal, desde que tenha um conteúdo 
Revista da Faculdade Mineira de Direito $\mid$ V.20 N.40 87

normativo compatível com os princípios e normas de um Estado Democrático de Direito estando com ele comprometida.

\section{REFERÊNCIAS}

[1]BOBBIO, Norberto. Liberalismo e democracia; tradução de Marco Aurélio Nogueira, São Paulo: Brasiliense, 200, p.16.

[2] idem, p. 19.

[3] FERRAJOLI, Luigi. Direito e razão: teoria do garantismo penal, 2 a edição, São Paulo: Editora Revista dos Tribunais, 2006, p. 15.

[4] BOBBIO, Norberto. Introdução. Em: Direito e Razão. São Paulo: RT, 2002, p. 9. ROXIN, Claus. Derecho Penal Parte General - TOMO I, $2^{\text {a }}$ ed Civitas, 1997, p. 164.

[4] ROXIN, Claus. Derecho Penal Parte General - TOMO I, $2^{\mathrm{a}}$ ed Civitas, 1997, p. 164.

[5] FERRAJOLI, Luigi. Direito e razão: teoria do garantismo penal, ..., op. cit. p.38.

[6] LUISI, Luiz. Os Principios Constitucionais Penais Porto Alegre: Editora: Sergio Antonio Fabris Editor, 2003.p. 21

[7] FERRAJOLI, Luigi. Direito e razão: teoria do garantismo penal, ... passim. 
Revista da Faculdade Mineira de Direito $\mid$ V.20 N.40 88

[8] HASSEMER, Winfied. Critica al derecho penal de hoy. Traducción de Patricia S. Ziffer. 2a ed. Buenos Aires: Ad Hoc, 2003. p. 24.

[9] DIAS,Jorge de Figueiredo. Direito Penal - parte geral - Tomo I - Questões Fundamentais; 2. ${ }^{a}$ Edição A Doutrina Geral do Crime. Coimbra: Editora: Coimbra Editora : 2012, p. @@

[10] ZAFFARONI, Eugenio Raúl; PIERANGELI, José Henrique. Manual de Direito Penal brasileiro: parte geral. 11. ed. São Paulo: Revista dos Tribunais, 1997. p.176.

[11] FERRAJOLI, Luigi. Direito e razão: teoria do garantismo penal, ..., op. cit. p.38.

[12] BRUNO, Aníbal. Direito Penal. Parte geral, Tomo I, $3^{\text {a }}$ edição. Rio de janeiro: Forense, 1967, p. 202.

[13] LUISI, Luis. Os Princípios Constitucionais Penais... op. cit.. p.21.

[14] FERRAJOLI, Luigi. Direito e razão: teoria do garantismo penal, ... p.35.

[15] MIR PUIG, Santiago. Introdución a las bases del derecho penal 2a . Ed Montevidéu - Buenos Ayres: Editorial B de f, 2003, p.13.

[16] PRADO, Luiz Regis. Curso de Direito Penal brasileiro. $12^{\mathrm{a}}$ ed. São Paulo: RT, 2013,6p. 232.

[17] LUISI, Luiz. Os Princípios Constitucionais Penais, op. cit. p. 20.

[18] ROXIN, Claus. Derecho Penal, Parte General - TOMO I, $2^{\mathrm{a}}$ ed Civitas, 1997, p. 140[19].

[19] DIAS,Jorge[de Figueiredo. Direito Penal ...op. cit. p183. 
Revista da Faculdade Mineira de Direito | V.20 N.40| 89

[20] BACIGAlUPO, Henrique. Princípios Constitucionais de Direito Penal. Buenos Aires: Editorial Hamurabi, p. 51.

[21] WESSEL, Joahannes. Direito penal, parte geral. Porto Alegre: Sergio Antonio Fabris Editor, p. 12.

[22] idem [23] ANTUNES Maria João. Medida de Segurança de Internamento e Facto Inimputável em Rąão de Anomalia Psíquica. Coimbra: Editora: Coimbra Editora, 2002, p. 65. [24] ROXIN, Claus. Derecho Penal Parte General - Tomo I, 2 ${ }^{\mathrm{a}}$ Ed Civitas, 1997, p. 164.

[25] idem, p.165.

[26] GONZÁLEZ, Félix María Pedreira. La prescripción de los delitos y de las faltas: Doctrina y jurisprudência. Madrid: Editorial Universitaria Ramon Areces, 2004, p.159.

[27] QUEIROZ, Paulo, VIEIRA, Antônio. Retroatividade da lei processual penal e garantismo. Disponível em: http://www.pauloqueiroz.net/retroatividade-da-lei-processual-penal-egarantismo. Acesso em: 21 dez. 2016

[28] CHIOVENDA, Giuseppe. Instituições de direito processual civil. Tradução Paulo Capitanio. $2^{a}$ ed. Campinas: Bookseller, 2002, p. 446-447.

[29] idem p. 446-450.

[30] LOPES JR., Aury. Direito processual penal, 12ª , São Paulo, Saraiva, 2015, p. 911.

[31] MARQUES José Frederico. Elementos de direito processual penal, vol. III, $2^{a}$ ed. Campinas: Millenium 2000, p. 200-201.

[32] idem, p. 91. 
Revista da Faculdade Mineira de Direito $\mid$ V.20 N.40 90

[33]TOURINHO FILHO, Fernando da Costa. Processo Penal. Vol. IV. $32^{a}$ ed. São Paulo: Saraiva, 2010, p.380.

[34]CÂMARA, Alexandre Freitas. Lições de Direito Processual Civil. São Paulo: Atlas, 2014, p.529-33.

[35] DIDIER JR, Fredie. BRAGA, Paula Sarno. OLIVEIRA, Rafael Alexandria de. Curso de direito processual civil. Vol. 11.10 a ed. Salvador: JUSPODIVM, 2015, p. 557.

[36] FUX, Luiz. Curso de direito processual civil. vol. 1, $3^{\text {a }}$ ed. Rio de Janeiro: Forense, 2005, p.822. 